\title{
RECONNAISSANCE SURVEY OF A GLAUCOUS EUCALYPT NEAR LOUISA BAY, SOUTHWESTERN TASMANIA
}

\author{
by Kristen J. Williams and Jon B. Marsden-Smedley
}

(with three tables, four text-figures, three plates and three appendices)

\begin{abstract}
Williams, K.J. \& MARSDEN-Smedley, J.B., 2000 (31:xii): Reconnaissance survey of a glaucous eucalypt near Louisa Bay, southwestern Tasmania. Pap. Proc. R. Soc. Tasm. 134: 45-54. ISSN 0080-4703. Forest Ecosystem Research and Assessment, Queensland Department of Natural Resources, 80 Meiers Road, Indooroopilly, Queensland, Australia 4068, formerly School of Plant Science, University of Tasmania (KJW); Fire Management Section, Parks and Wildlife Service, Department of Primary Industries, Water and Environment, GPO Box 44A, Hobart, Tasmania, Australia 7001(JBM-S).
\end{abstract}

Stands of a glaucous eucalypt in the vicinity of Louisa Bay, southwestern Tasmania, which has affinities to Eucalyptus tenuiramis (Series Piperitae), were surveyed in order to determine their taxonomic status and record aspects of their population ecology. Two main populations were observed in scattered stands among predominantly moorland vegetation at the Red Point Hills and Louisa Plains. One stand from each population was accessed for detailed study. Contiguous plots located along transects across the copses were used to record changes in population status, floristics and site conditions. Individuals of the glaucous eucalypt were small in stature and frequently malleeform near the moorland boundary, but were taller $(10-12 \mathrm{~m})$ and straight with single, slender main stems toward the centre of the copse. The Red Point Hills stand comprised a larger number of smaller individuals than the Louisa Plains stand and had been subject to at least three fires in the last 65 years, whereas only one fire had occurred on the Louisa Plains in the same period. These observations have implications for fire management: an appropriate regime, which encourages regeneration around the stand margins rather than increasing the edge-effects, needs to be devised. Given the geographic discontinuity with Eucalyptus tenuiramis, the southwestern copses may represent a relict dry sclerophyll community that was once contiguous with eastern Tasmania during the height of the last glaciation. Key Words: Eucalyptus tenuiramis, southwestern Tasmania, Louisa Bay.

\section{INTRODUCTION}

Eucalyptus nitida is the dominant eucalypt species across most of lowland southwestern Tasmanian scrub boundaries and copses (Brown \& Podger 1982, Jarman et al. 1982, 1988, Balmer 1990, Marsden-Smedley 1990, MarsdenSmedley et al. 2000a). However, there have been reports of an unusual eucalypt from the plains behind Louisa Bay for more than 20 years (R.G. Tyson, pers. comm.; J.B. Kirkpatrick, pers. comm.). These reports included a single photograph (pl. 1), which was taken by R.G. Tyson in the 1970 s near Ningher Creek to the east of Louisa Bay, and was passed on to B. Potts at the Department of Plant Science, University of Tasmania, for identification. The picture showed what appeared to be a highly glaucous, mallee-form eucalypt (2-3 $\mathrm{m}$ tall) in the peppermint group (Series Piperitae, after Pryor \& Johnson 1971). Although this is similar in appearance to either Eucalyptus tenuiramis or $E$. coccifera, the plains behind Louisa Bay fall well outside the climatic, substrate or geographic ranges of both species (Williams \& Potts 1996).

Knowing that we were intending to visit Louisa Bay during a bushwalk in the late 1980 s, B. Potts requested that we access the known population of this species and collect specimens for taxonomic identification and genetic studies. J. Kirkpatrick (Department of Geography, University of Tasmania) subsequently brought our attention to the more extensive stands of this eucalypt on the southern end of the Red Point Hills, to the west of Louisa Bay, which he had observed during flights between Hobart and Melaleuca. Therefore, it appeared that the species might more extensive than previously thought - occurring to both the east and west of Louisa Bay.
On those earlier walking trips, no glaucous eucalypts were seen adjacent to the route which is normally traversed on the way to Louisa Bay (from the Spica Hills south to the northwestern end of Louisa Beach). However, on a flight over the region in January 1992, we observed what Kirkpatrick had previously noted: an extensive mosaic of the species on the Red Point Hills to the west of Louisa Bay. We also observed several small stands of the glaucous eucalypt to the east of Louisa Bay, near where R.G. Tyson had reported it in the 1970s. The observation was fortuitous, occurring because the glaucous foliage reflected the late afternoon sun, temporarily distinguishing it from the brightgreen foliage of the adjacent Eucalyptus nitida.

With the assistance of S. Corbett (Vegetation Mapper for the Southwest Wilderness World Heritage Area) and colour aerial photography, we identified a series of potential stands of this eucalypt. These were clearly well away from existing walking routes and would require a specific survey to access and collect specimens to clarify their identity. Previous discussions with $M$. Neyland (Forestry Tasmania) had suggested that the lowland plains below the Red Point Hills were covered by extensive bands of wet scrub, and that a better route might be via the summit of the Red Point Hills. This is the route we followed in our March 1996 survey. The primary objectives of the freld survey were to collect herbarium voucher specimens (including fruit and seeds) for formal taxonomic identification and genetic studies. A secondary objective was to record the population status of the eucalypt and its associated habitat. An account of these findings is presented here. Due to its glaucous foliage, lowland distribution and superficial resemblance to Eucalyptus tenuiramis, we refer to the population by the name Eucalyptus aff. tenuiramis (Louisa 


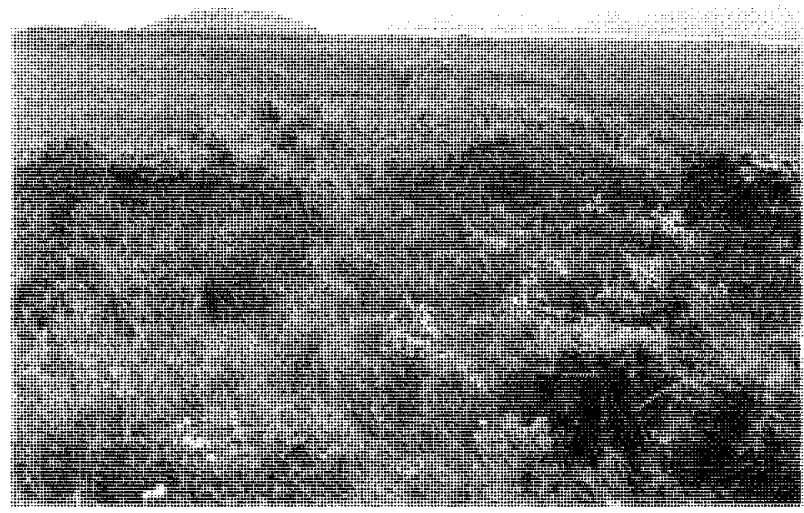

PLATE 1

Glaucous mallee-form eucalypt near Ningher Creek on the Louisa Plains. (Photograph taken by R. G. Tyson in the 1970s.)

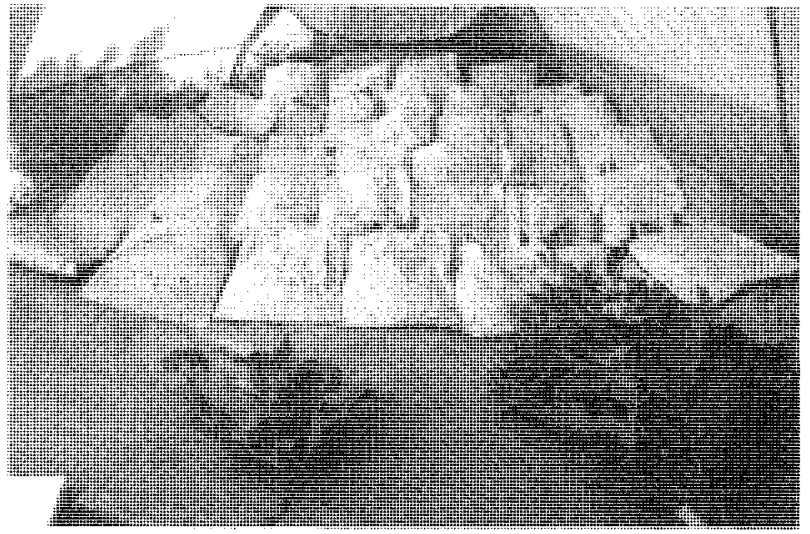

PLATE 3

Field drying of voucher specimens and capsules.

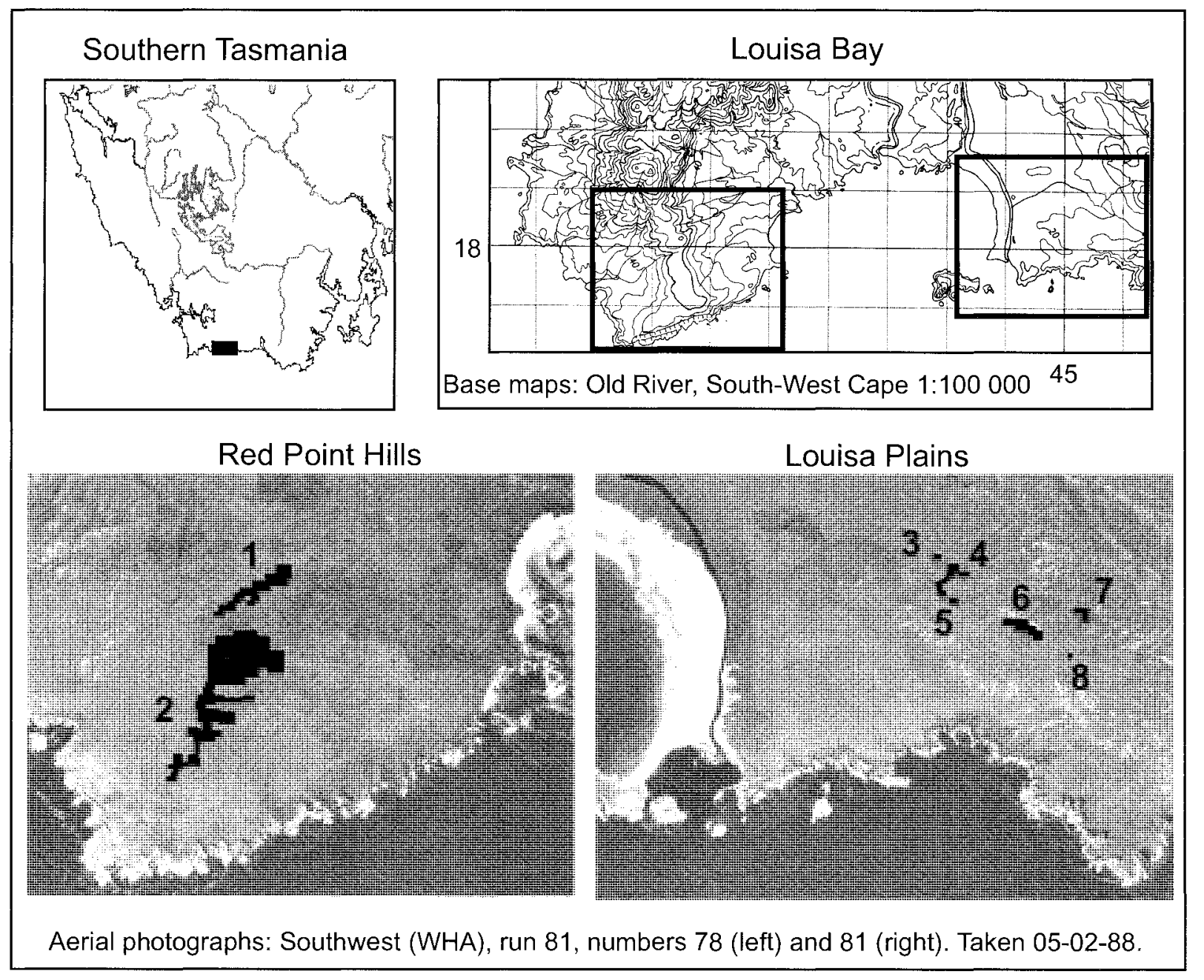

PLATE 2

Location of study area and individual copses of Eucalyptus aff. tenuiramis (Louisa Bay) in the vicinity of Louisa Bay, southwestern Tasmania. Note: copse 7 is shown in pl. I while the copse sampled on the Red Point Hills is copse 1 and the copse sampled on the Louisa Plains is copse 6. 
Bay). Recent genetic studies based on the seed collected during this field reconnaissance survey indicated that this species is in fact a subspecies of Eucalyptus tenuiramis (Turner 1999).

\section{METHODS}

\section{Study Area}

The Red Point Hills and Louisa Plains are located on the south coast of Tasmania about $20 \mathrm{~km}$ southeast of Melaleuca in southwestern Tasmania (pl. 2). The region consists of undulating plains $20-60 \mathrm{~m}$ a.s.l., and low hills up to $275 \mathrm{~m}$ a.s.l. To the north and east the region is surrounded by higher country consisting of Mt Louisa and the Ironbound Range (about 950 and $800 \mathrm{~m}$ a.s.l. respectively). The region is underlain by Precambrian phyllite (Brown et al. 1995). The region has been included in the South-West National Park and forms part of the Tasmanian Wilderness World Heritage Area.

Potential stands were identified using 1:25000 colour aerial photographs taken in 1988 (pl. 2). These stands were identified by their glaucous colouration and mallee to small-tree form, and were ranked by their likelihood of containing the target eucalypt. Potential stands were traced onto 1:25000 topographic base maps for verification during the field reconnaissance survey.

\section{Field Surveys}

The field reconnaissance survey was undertaken between 4 and 7 March 1996, primarily to collect herbarium voucher and seed specimens from stands located both to the east (Louisa Plains) and west (Red Point Hills) of Louisa Bay. During this survey, two copses were sampled: copse 1 from the Red Point Hills and copse 6 from the Louisa Plains (pl. 2 and table 1). The population status, floristic composition and site conditions were also assessed.

\section{Seed and voucher specimen collection}

Seed in mature capsules were collected from six to ten nonadjacent individual trees. Capsules and representative leaves (fully expanded new seasons' growth) were stored in paper collection bags. Herbarium voucher specimens were collected from the same trees and arranged in a field press. Juvenile material was collected from coppice on these trees, where available, or from other individuals. Individual tree material was strictly separated and labelled. A description of each sampled tree (height, diameter, growth form) and its associated habitat (site conditions, dominant understorey species) were noted. The sampled trees were generally located within plots associated with each transect, but not exclusively.

Drying of voucher specimens and capsules was initiated under field conditions as far as practical (pl. 3). Voucher specimens were lodged with the Tasmanian Herbarium (table 2), while seed and capsule collections were lodged with the Department of Plant Science, University of Tasmania.

TABLE 1

Location and extent of the Eucalyptus aff. tenuiramis (Louisa Bay) in the vicinity of Louisa Bay

\begin{tabular}{|c|c|c|c|c|c|c|}
\hline Number and location & Easting & Northing & Size (ha) & Stand type & Altitude & $10 \mathrm{~K}$ grid \\
\hline 1 Red Point Hills & 443300 & 5180200 & 10 & high density large copse & 120 & 4418 \\
\hline 2 Red Point Hills & 443200 & 5179500 & 30 & medium density scrub mosaic & 70 & 4417 \\
\hline 3 Louisa Plains & 450300 & 5181300 & 1 & small low copse & 20 & 4518 \\
\hline 4 Louisa Plains & 450600 & 5181000 & 5 & small low copse & 20 & 4518 \\
\hline 5 Louisa Plains & 450500 & 5180700 & 2 & small low copse & 20 & 4518 \\
\hline 6 Louisa Plains & 451100 & 5180600 & 3 & high density copse & 40 & 4518 \\
\hline 7 Louisa Plains & 451400 & 5180700 & 2 & small low copse & 60 & 4518 \\
\hline 8 Louisa Plains & 451400 & 5180300 & 1 & small low copse & 40 & 4518 \\
\hline Total area & & & 54 & & & \\
\hline
\end{tabular}

TABLE 2

Voucher specimens Eucalyptus aff. tenuiramis (Louisa Bay) lodged with the Tasmanian Herbarium

\begin{tabular}{|c|c|c|c|c|c|c|}
\hline \multirow{3}{*}{$\frac{\text { Collection location }}{\text { Red Point Hills }}$} & \multicolumn{6}{|c|}{ Identification numbers } \\
\hline & HO442472 & HO442491 & HO442493 & HO442494 & HO442495 & HO442482 \\
\hline & HO442490 & HO442492 & & & & \\
\hline Louisa Plains & HO442333 & HO442516 & HO442517 & HO442499 & $\mathrm{HO} 442500$ & HO442518 \\
\hline
\end{tabular}


Descriptions of each seed tree are given in appendix 1 . A full copy of the data collected has been lodged with the World Heritage Area Botanist, Department of Primary Industries, Water and Environment.

\section{Population ecology}

The relative health and regeneration status of rare taxa are of particular interest for conservation management planning. This field survey aimed to evaluate aspects of the population ecology of the target eucalypt using one transect in each of the copses sampled (see above). Each transect was located normal to the moorland-copse boundary and sampled by contiguous $10 \times 10 \mathrm{~m}$ plots from moorland through forest to moorland on the opposite side. Seven plots were located along the Red Point Hills transect $(70 \mathrm{~m})$, and six plots along the Louisa Plains transect $(60 \mathrm{~m})$. At each plot, floristic composition and vegetation structure were recorded along with site conditions and eucalypt population status (table 3 ). With the exception of the glaucous eucalypt described in this paper, which has been termed Eucalyptus aff. tenuiramis (Louisa Bay), species terminology follows Buchanan (1995).

A numerical index, in five levels, was used to describe individual tree "healthiness" ( $1=$ good; $2=$ medium to good; 3 = medium to poor; $4=$ poor; $5=$ dead). Individual tree health was subjectively assessed by observing the integrity of leaf margins (i.e. degree of herbivory), density of galls, leaf colour, lesions and blemishes (e.g. degree of stress-induced redness or microbial disease), vigour and abundance of new season's growth, and presence or abundance of coppice regrowth (indicating loss of apical dominance by crown).

A descriptive account of the trends in population status of $E$. aff. tenuiramis for each transect was based on observations of stem density, canopy height, stem diameter, growth stage and overall plant health within each $100 \mathrm{~m}^{2}$ plot. The trend in substrate depth is shown for the Red Point Hill transect, but was not measured at the Louisa Plains transect (because the wire pin was lost in the scrub between sites).

\section{Floristic trends}

Trends in the change in vascular plant species with distance along each transect were recorded. Floristic associations are described and compared with published accounts of comparable vegetation types from dry sclerophyll (Duncan \& Brown 1985) and moorland (Jarman et al. 1988).

\section{RESULTS}

\section{Aerial Photograph Interpretation}

Aerial photograph interpretation indicated about 54 ha of the glaucous eucalypt in eight patches (pl. 2, table 1). Most of the area ( $30 \mathrm{ha}$ ) was attributed to one large mosaic of the glaucous eucalypt interspersed by small areas of wet scrub in the vicinity of the Red Point Hills. The Louisa Plains population was notably dispersed and local among several small stands, whereas the Red Point Hills population was more contiguous across the low hills above Contact Cove.

\section{Field Surveys}

\section{Population ecology}

The overall trends in tree size and growth stage observed for the two eucalypt populations are given in figure 1 . The Red Point Hills population had a larger proportion of multistemmed adult individuals and fewer juveniles than the Louisa Plains population. In both populations, growth stages were dominated by juveniles, coppice or mallee-form trees at the moorland-copse boundary, whereas larger, single-stemmed trees dominated towards the centre of each copse.

Trends in stand performance (mean canopy height, basal area, stem density and relative health) of the $E$. aff. tenuiramis populations along the Red Point Hills and Louisa Plains transects are displayed in figures 2 and 3, respectively. In each case, mean stand canopy height diminished to less than $2 \mathrm{~m}$ at the copse-moorland boundary and increased to about $12 \mathrm{~m}$ toward the centre of each copse. Mean tree basal area also varied from the margin to the centre of the copse, from about $30 \mathrm{~cm}^{2}$ per $100 \mathrm{~m}^{2}$ (tree diameters of $5-6 \mathrm{~cm}$ ) to about $800 \mathrm{~cm}^{2}$ per $100 \mathrm{~m}^{2}$ (about $30 \mathrm{~cm}$ diameter). Our subjective assessment of stand health also indicates that less optimal growing conditions were experienced by individuals located adjacent to the moorland than at the centre of the copse.

The soils of both copses were generally shallow, being shallowest on the northern aspects where the substrate seemed almost skeletal on bedrock and gravel. Variation in substrate depth was observed at the Red Point Hills site (fig. 4). Substrate depth closely corresponded with trends

TABLE 3

Survey methods used to assess floristic composition and population status of Eucalyptus aff. tenuiramis (Louisa Bay)

Attribute Description of method

Vegetation structure

Floristic composition

Eucalypt population ecology
Estimated height, projective-foliage cover and species dominance ranking in major structural layers: tree, shrub and ground strata.

Floristic list of all vascular plant species with Braun-Blanquet percentage cover-abundance ratings.

Height and diameter (stem above basal swelling) of each individual in $10 \times 10 \mathrm{~m}$ plots, number and size of individual stems if mallee-form, presence or absence of lignotuber, tree health index ( 1 = good $-5=$ dead, see text), reproductive status (juvenile, coppice, adult-vegetative, adultreproductive). 
in eucalypt tree size and density. Relatively shallow soils ( $<50 \mathrm{~cm}$ depth) generally corresponded with increasing basal area and height of the copse. At moorland-copse boundaries, substrate depths increased abruptly, and in the moorland proper, the peat soils were very deep $(>1.0 \mathrm{~m})$ and frequently quaked at each step.

Trends in fire age were observed from the number of branch nodes of Banksia marginata and basal ring counts from Leptospermum spp., as well as fire history mapping from aerial photographs (Marsden-Smedley 1998). These indicated that both the sites were burnt in 1933/34, with the Red Point Hills population subsequently being burnt in 1948 and partly in 1976 (the fire did not penetrate to the centre of the copse, appendix 2). These differences in fire history may have some relationship to observed differences in stand structure and health (figs 1-3).

\section{Floristic trends}

A list of the vascular plant species recorded along each transect and their relative abundance are given in appendix 3 . The vegeration at the centre of the $E$. aff. tenuiramis copses is best described as closed wet scrub. Turnover in species composition along transects is associated with distance from the moorland-copse boundary and changes in substrate
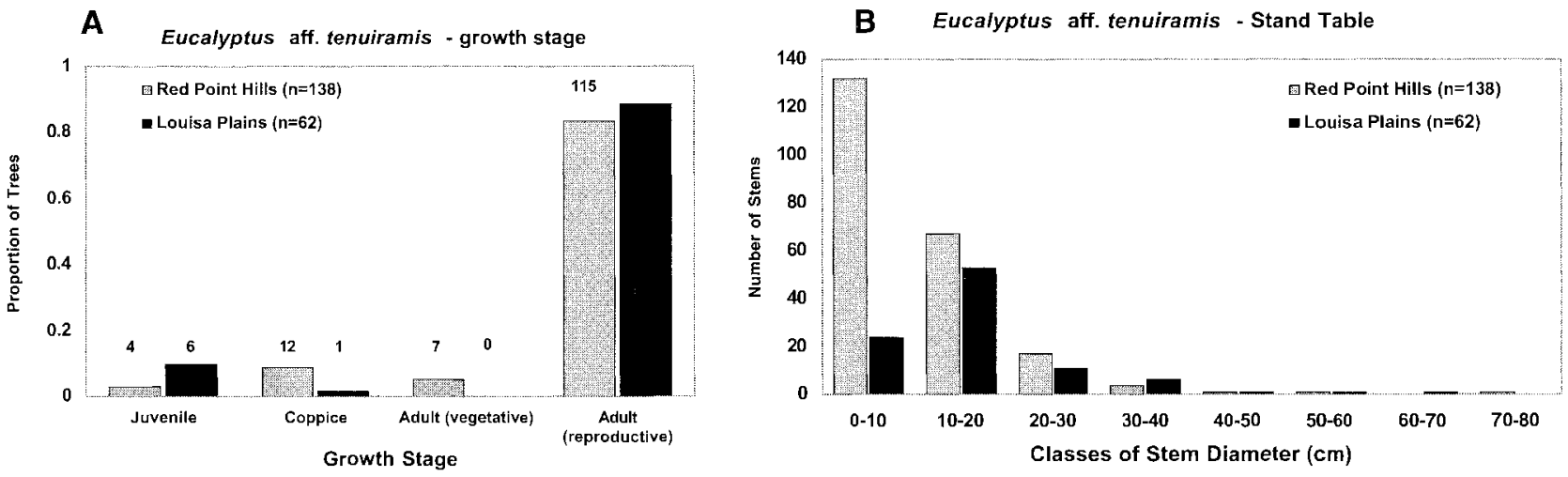

FIG. 1 - Trends in (A) growth stage and (B) stem diameter of $\mathrm{E}$. aff. tenuiramis (Louisa Bay) for the two transects. Numbers on graphs indicate sample size.

A

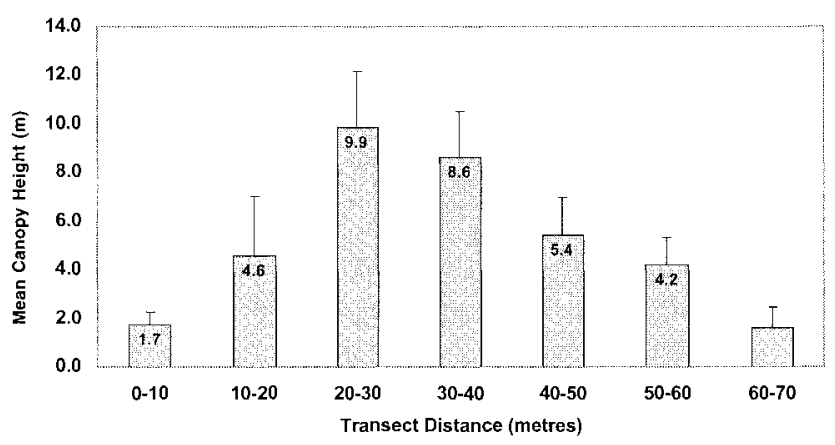

C

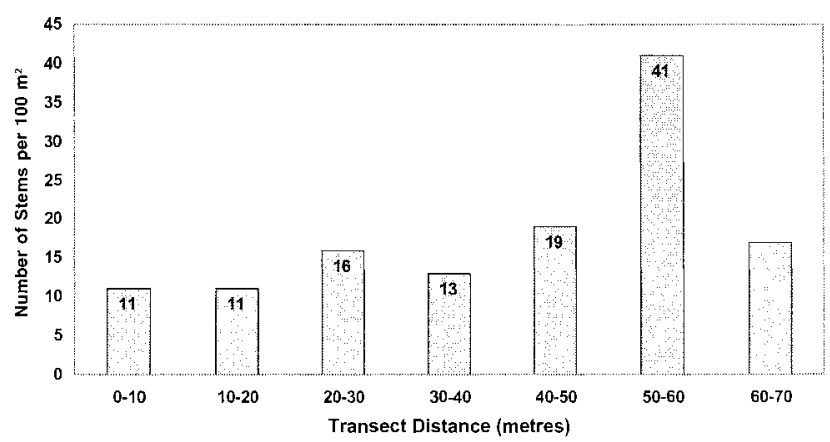

B

Red Point Hills - Mean Tree Basal Area

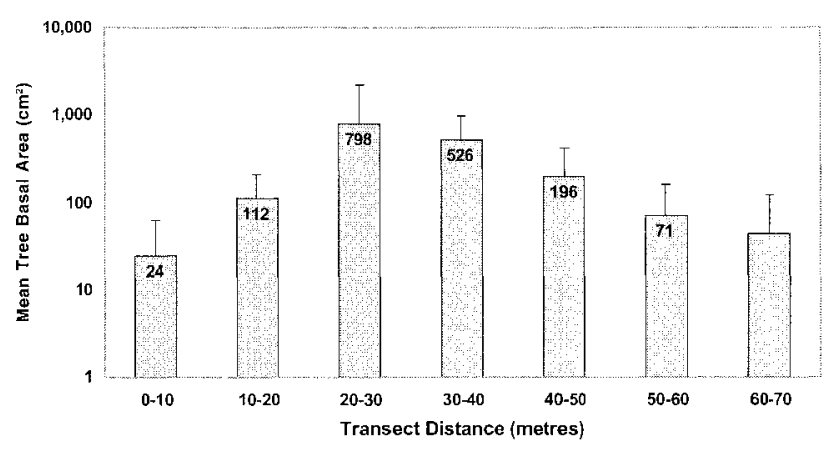

D Red Point Hills - Mean Stand Health Index

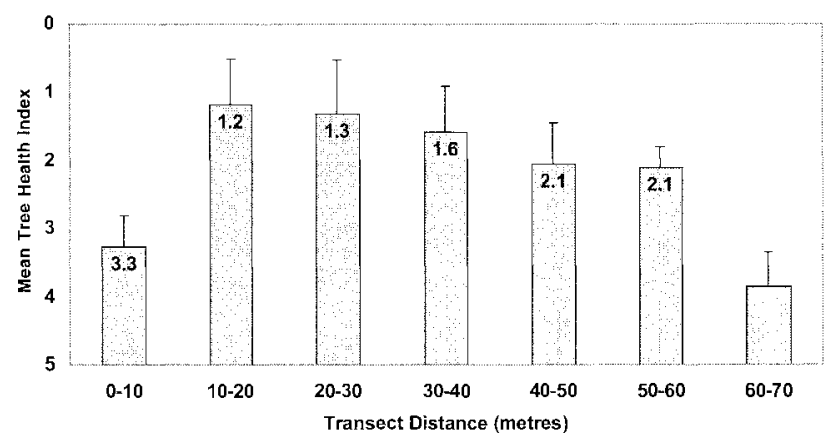

FIG. 2 - Trends in performance of the Red Point Hills population of Eucalyptus aff. tenuiramis (Louisa Bay): (A) canopy height, $(B)$ stand basal area, $(C)$ stem density and $(D)$ stand health index (see text, p.48). Error bars indicate standard deviation. 
A

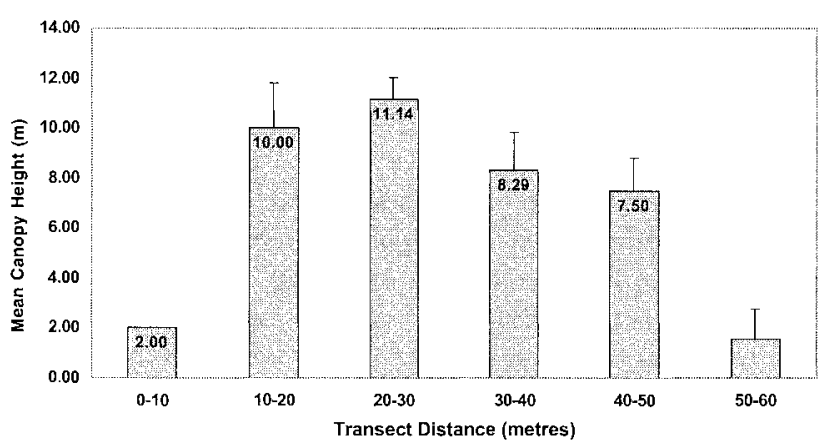

C

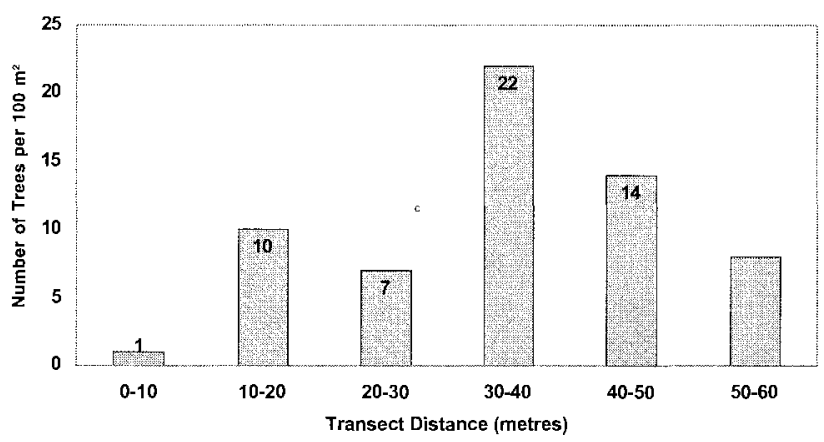

B Louisa Plains - Mean Tree Basal Area

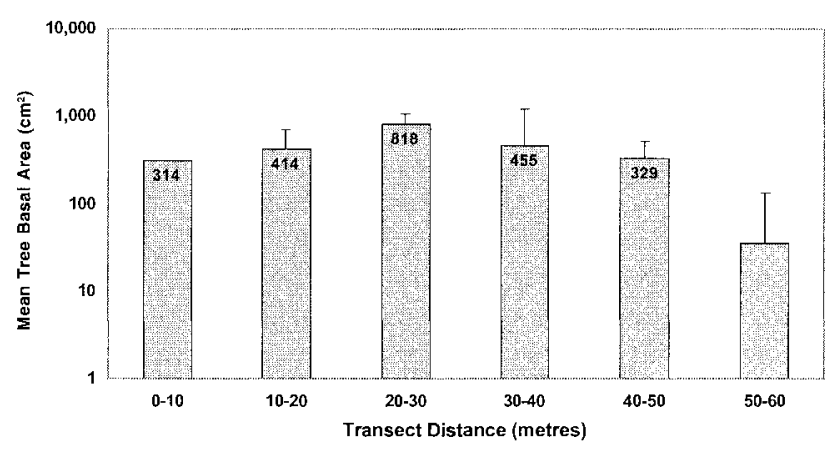

D Louisa Plains - Mean Stand Health Index

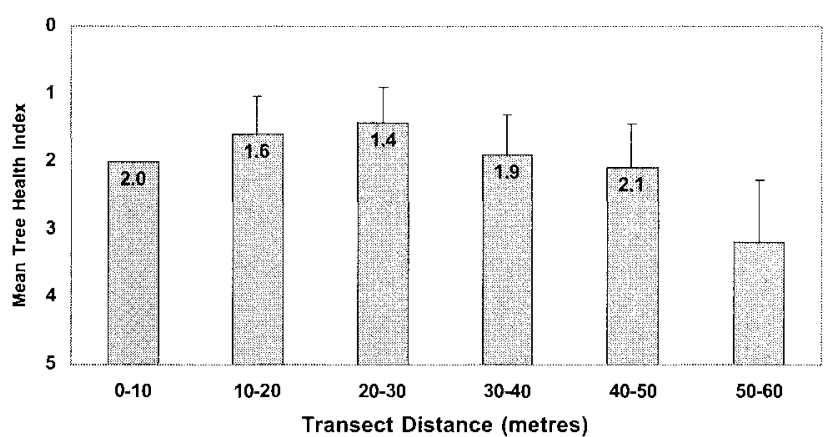

FIG. 3 - Trends in performance of the Louisa Bay population of Eucalyptus aff. tenuiramis (Louisa Bay): (A) canopy height, (B) stand basal area, $(C)$ stem density and (D) stand health index. Error bars indicate standard deviation.

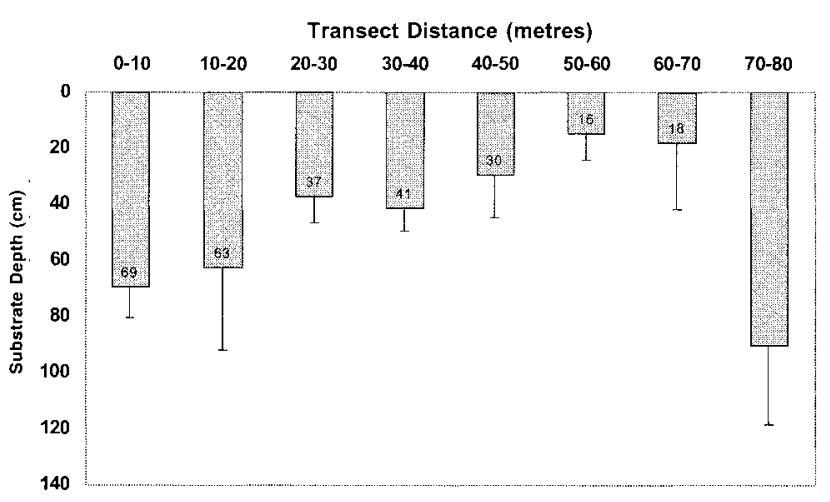

FIG. 4- Trends in substrate depth along the Red Point Hills transect. Error bars indicate standard deviation.

depth and soil type. These changes are typical of woodland copses surrounded by moorland (e.g. Jarman et al. 1988, Marsden-Smedley 1990, Marsden-Smedley et al. 2000a). However, although the vegetation of the copses dominated by $E$. aff. tenuiramis floristically differed from those previously described for $E$. nitida, its closest affinities appear to be with the Dry-domed Copse (Type 12B) community types described by Jarman et al. (1988).

The copse vegetation was dominated by dense stands of $E$. aff. tenuiramis with a wet scrub understorey comprising species such as Gabnia grandis and Zieria arborescens, which are commonly found in disturbed wet forests following fire. Wet scrub species, such as Melaleuca squarrosa, Banksia marginata and Baueria rubioides, which are commonly found across moorland-copse boundaries, tended to occur throughout the copse, only declining in density toward the centre. The occurrence of these species further reinforced the suggestion that recurrent fire and the small size of the stands resulted in edge effects that penetrate throughout the copse, declining in intensity toward the centre.

Less common shrub and heath species included Monotoca glauca, Epacris impressa, Leucopogon collinus, Pultenaea daphnoides, P. juniperina, Acacia myrtifolia and Pimelea linifolia. These may represent relicts of the former forest type that might be more abundant if the patch sizes had been large enough to dissipate the edge effects. The lilies Drymophila cyanocarpa and Dianella tasmanica and the bracken fern Pteridium esculentum were also considered indicator species of the relict vegetation type. It appears that the relict vegetation type might have been a drier forest or open woodland than is at present typical of copses dominated by Eucalyptus nitida in southwestern Tasmania. Several species that are more typical of wet scrubs and woodland mosaics in southwestern Tasmania were also found in the copses. The most abundant species of this sort were Lomatia polymorpha and Acacia verticillata. Lomatia polymorpha appeared to fill the niche of its eastern relative L. tinctoria.

\section{DISCUSSION}

The copse vegetation appeared more typical of a drier forest type, such as might be found in southeastern Tasmania (Duncan \& Brown 1985) than that expected of a typical buttongrass moorland copse (Jarman et al. 1988, MarsdenSmedley et al. 2000a). This observation was based on 
indicator species with low abundances such as Leucopogon collinus, Pulteneaea daphnoides and Acacia myrtifolia, and the fact that individuals of the glaucous eucalypt appeared most like the southeastern forms of E. tenuiramis in dry sclerophyll forest. This might be consistent with the relict origin of this species from habitats that were once contiguous with eastern Tasmania (Turner 1999).

On the moorland-copse boundary, individuals of $E$. aff. tenuiramis were small in stature and frequently malleeform. Toward the centre of the forest copse, they were taller $(10-12 \mathrm{~m})$ and straight with single, slender main stems. Juvenile leaves, buds and fruit, in particular, were highly glaucous and even the thick, shiny adult leaves were waxy.

The relative health and regeneration status of the two eucalypt populations from Louisa Plains and Red Point Hills differed. The smaller Louisa Plains population was most notable for the heavy load of seed-capsules from the previous year - weighing down the slender branches, but there were relatively few buds for the current year and virtually no new season's growth. By contrast, a much lighter seed crop was observed from the Red Point Hills population and abundant new growth was apparent. The distribution of size classes for stem diameters from the Red Point Hills stand (fig. 1B) indicated that several regeneration events had occurred in the recent past which are probably related to the fire events in 1933/34, 1948 and 1976. By contrast, the lack of similar regeneration as small size classes $(0-10 \mathrm{~cm}$ basal stem diameter) at the Louisa Plains stand (last burnt in 1933/34) suggests a dependence on fire for seedling establishment. However, the Louisa Plains stand is also smaller than the Red Point Hills site, resulting in edge effects that may further contribute to the overall poorer health of individual trees (fig. 3D).

These results suggest that the long-term viability of $E$. aff. tenuiramis on Louisa Plains maybe questionable, due to its small area and the dispersed nature of its stands. The more extensive mosaics of the glaucous eucalypt on the Red Point Hills are likely to be more secure over the long term. It is also possible that other unknown relict species or genotypes of the former vegetation type may co-exist with the eucalypt in this area, and/or in similar habitats near by. For example, one of the authors (JM-S), has observed a similarly highly glaucous eucalypt on the lower slopes of Mt Wright in the Vale of Rasselas (J. M-S, pers. obs.).

The observations described in this paper have implications for fire management in the vicinity of Louisa Bay and the Red Point Hills, where a trade-off may exist between capacity to regenerate and edge effects. An appropriate fire regime, which encourages regeneration around the stand margins rather than increasing the edge-effects, needs to be devised. Such a fire regime could potentially be implemented through prescribed burning in the vicinity of these stands during periods of low fire danger and when soils are saturated (e.g. when the Moorland Fire Danger Rating and Soil Dryness Rating are both below five - Marsden-Smedley et al. 2000).

\section{ACKNOWLEDGEMENTS}

This work was initiated as a result of field observations by R.G. (Bob) Tyson. Repeated requests from Brad Potts to collect seed during recreational bushwalks led to this more specific reconnaissance survey. We are grateful to Sib Corbett for assistance with aerial photograph interpretation. Thanks to Jayne Balmer, who facilitated official approval for the survey and arranged assistance from the Australian Geographic Expedition helicopter, operating in the area at the time.

\section{REFERENCES}

Balmer, J.M., 1990: Two moorland boundaries. Tasforests 2: 133-141.

Brown, A.V., Calver, C.R., Corbett, K.D., Forsyth, S.M., Goscombe, B.A., Green, G.R., McClenaghan, M.P., Pemberton, J. \& Seymour, D.B., 1995: GEOLOGYOF SOUTHWEST TASMANIA 1:250 000. Tasmanian Geological Survey, Mineral Resources Tasmania, Hobart, Tasmania.

Brown, M.J. \& Podger, F.D., 1982: Floristics and fire regimes of a vegetation sequence from sedgeland heath to rain forest at Bathurst Harbour, Tasmania. Aust. J. Bot. 30: 659-676.

BUCHANAN, A.M., 1995: A CENSUS OF THE VASCULAR PLANTS OF TASMANIA AND INDEX TO THE STUDENTS FLORA OF TASMANIA. Tasm. Herb. Occ. Publ. 5. Tasmanian Herbarium, Hobart, Tasmania.

DUNCAN, F. \& BROWN, M.J., 1985: DRY SCLEROPHYLL VEGETATION IN TASMANIA: EXTENT AND CONSERVATION STATUS OF THE COMMUNITIES. Wildl. Div. Tech. Rep. 85/1. National Parks and Wildlife Service, Tasmania.

Jarman, S.J., Crowden, R.K. \& Brown, M.J., 1982: A descriptive ecology of the vegetation in the lower Gordon River basin, Tasmania. Pap. Proc. R. Soc. Tasm. 116: 165-177.

Jarman, S.J., Kantvilas, G. \& Brown M.J., 1988: BUTTONGRASS MOORIAND IN TASMANIA. Res. Rep. 2. Tasmanian Forest Research Council Inc., Hobart, Tasmania.

Marsden-Smedley, J.B., 1990: The ecology of moorland-copse boundaries in southwest Tasmanian oligotrophic environments. Unpubl. Honours thesis, Dep. Plant Sci., Univ. Tasm.

Marsden-Smedley, J.B., 1998: Changes in the fire regime of southwest Tasmania over the last 200 years. Pap. Proc, $R$. Soc. Tasm. 132: 15-29.

Marsden-Smedley, J.B., Brown, M.J. \& Reid, J.B., 2000a: The ecology of buttongrass moorland - wet scrub boundaries in southwest Tasmania. Austral Ecol.

Marsden-Smedley, J.B., Rudman, T., Catchpole, W. R. \& PYrke, A., 2000b: Buttongrass moorland fire behaviour prediction and management. Tasforests 11: 87-107.

Mueller-Dombois, D. \& Ellenberg, H., 1974: AIMS AND METHODS OF VEGETATION ECOLOGY. John Wiley and Sons, New York.

PRYOR, L. D. \& JOHNSON, L.A.S., 1971: A CLASSIFICATION OF THE EUCALYPTS. Australian National University Press, Canberra, ACT, Australia.

TurNer, C.L., 1999: Morphological and allozyme differentiation in the Eucalyptus risdonii Hook.f. - E. tenuiramis Miq. complex. Unpubl. Honours thesis, School Plant Sci., Univ. Tasm.

Wilidams, K.J. \& PotTs, B.M., 1996: The natural distribution of Eucalyptus species in Tasmania. Tasforests 8:39-165. 
APPENDIX 1

Location and description of each seed tree

\begin{tabular}{|c|c|c|c|c|c|c|c|c|c|c|c|}
\hline Tree_id ${ }^{*}$ & Easting & Northing & Altitude $(\mathrm{m})$ & Height $(\mathrm{m})$ & Glaucousness & Form Description & $\begin{array}{c}\text { Stem } 1 \\
(\mathrm{~cm})\end{array}$ & $\begin{array}{c}\text { Stem2 } \\
(\mathrm{cm})\end{array}$ & Site Description & Reproductive status & Comments \\
\hline R_Treel & 443400 & 5180200 & 120 & 4 to 5 & sub-glaucous & $\begin{array}{l}\text { Mallee, 2-major branches from } \\
\text { lignotuber, other branches dead }\end{array}$ & 10 & 5 & Edge of moorland & Moderate seed crop & - \\
\hline R_Tree2 & 443450 & 5180150 & 120 & 4 to 5 & sub-glaucous & Mallee, one small, one large stem & 20 & 2 & - & - & - \\
\hline R_Tree3 & 443300 & 5190150 & 120 & 6 & $\begin{array}{l}\text { glaucous stems, } \\
\text { otherwise } \\
\text { subglaucous }\end{array}$ & single stem sapling & - & - & Tall scrubby-forest & - & - \\
\hline R_Tree4 & 443300 & 5180200 & 120 & 6 to 8 & - & $\begin{array}{l}20 \text { to } 25 \mathrm{~cm} \text { diameter at base, } \\
80 \mathrm{~cm} \text { to bole then two branches }\end{array}$ & 15 & 5 & - & - & - \\
\hline R_Trees & 443450 & 5180050 & 120 & 6 to 8 & - & $\begin{array}{l}35 \mathrm{~cm} \text { basal diameter, single stem, } \\
\text { second branch at } 1.5 \mathrm{~m} \text { height - dead }\end{array}$ & 35 & - & $\begin{array}{l}\text { Tall scrub Banksial } \\
\text { Melaleuca understorey } \\
6-8 \mathrm{~m} \text {, with Zierial } \\
\text { Monotoca } 4-6 \mathrm{~m}\end{array}$ & - & - \\
\hline R_Tree6 & 443450 & 5180050 & 120 & 8 to 10 & - & Two main stems & 35 & 25 & $\begin{array}{l}\text { Wet scrub forest, dense } \\
\text { canopy of E. aff. } \\
\text { tenuiramis } 60 \% \text { FPC }\end{array}$ & - & - \\
\hline R_Tree7 & 443450 & 5180050 & 120 & 10 to 12 & - & Single stem - basal stem diameter & 35 & - & $\begin{array}{l}\text { Scrub Melaleuca forest, } \\
\text { open dark understorey }\end{array}$ & - & - \\
\hline R_Tree8 & 443550 & 5180000 & 120 & 1 to 1.5 & - & Mallee & - & - & Scrub-moorland & - & - \\
\hline R Tree9 & 443450 & 5180200 & 120 & 4 to 6 & - & One main stem $15-20 \mathrm{~cm}$ diameter & $15-20$ & - & $\begin{array}{l}\text { Low mallee-scrub, third } \\
\text { tree in from moorland } \\
\text { edge }\end{array}$ & - & - \\
\hline L_Treel0 & 451100 & 5180450 & 40 & 4 to 5 & sub-glaucous & Mallee, 3 to 4 main stems & - & - & Copse edge & $\begin{array}{l}\text { Heavy crop of seed } \\
\text { from previous year - } \\
\text { drought? }\end{array}$ & $\begin{array}{l}\text { Moderate to } \\
\text { poor health }\end{array}$ \\
\hline L_Treel1 & 451100 & 5180600 & 40 & 7 & - & Small tree, single stem & $15-20$ & - & $\begin{array}{l}\text { Distance }-6 \text { to } 10 \text { trees } \\
\text { from toward centre of } \\
\text { copse from Tree } 10\end{array}$ & - & - \\
\hline L_Treel2 & 451100 & 5180600 & 40 & 10 & - & Small tree, single stem & 25 & - & $\begin{array}{l}\text { Middle of copse, steep } \\
\text { slope, scrubby wet forest }\end{array}$ & - & - \\
\hline L_Tree13 & 451100 & 5180600 & 40 & 9 & - & Small tree & 25 & - & $\begin{array}{l}\text { Middle of copse, steep } \\
\text { slope, scrubby wet forest }\end{array}$ & - & - \\
\hline L_Tree14 & 451100 & 5180600 & 40 & 10 & - & Small tree & 25 & - & $\begin{array}{l}\text { Near lower southern } \\
\text { boundary of copse, } \\
\text { sedgey closed forest } \\
\text { understorey }\end{array}$ & - & - \\
\hline L_Tree15 & 451100 & 5180600 & 40 & 4 & - & $\begin{array}{l}\text { Small tree, several stems } 5-10 \mathrm{~cm} \\
\text { from a } 1-2 \mathrm{~m} \text { diameter lignotuber }\end{array}$ & 25 & - & $\begin{array}{l}\text { Off ridge on edge of } \\
\text { moorland }\end{array}$ & \multicolumn{2}{|l|}{$\begin{array}{l}\text { Heavy seed crop, some } \\
\text { branches laden with fruir - }\end{array}$} \\
\hline
\end{tabular}

${ }^{*} \mathrm{R}=$ Red Point Hills, $\mathrm{L}=$ Louisa Plains. 
APPENDIX 2

Site conditions recorded along the Red Point Hills and Louisa Plains transects

\begin{tabular}{|c|c|c|c|c|c|c|c|c|c|c|c|c|c|}
\hline & \multicolumn{7}{|c|}{ Red Point Hills Transect } & \multicolumn{6}{|c|}{ Louisa Plains Transect } \\
\hline & $0-10$ & $10-20$ & $20-30$ & $30-40$ & $40-50$ & $50-60$ & $60-70$ & $0-10$ & $10-20$ & $20-30$ & $30-40$ & $40-50$ & $50-60$ \\
\hline Site Condition & $\mathrm{R} 1$ & $\mathrm{R} 2$ & R3 & $\mathrm{R} 4$ & $\mathrm{R} 5$ & R6 & $\mathrm{R} 7$ & $\mathrm{~L} 1$ & $\mathrm{~L} 2$ & $\mathrm{~L} 3$ & $\mathrm{~L} 4$ & L5 & L6 \\
\hline Last Fire (year) & 1976 & 1976 & 1976 & 1948 & 1948 & 1976 & 1976 & $\begin{array}{r}1933 / \\
1934\end{array}$ & $\begin{array}{c}1933 / \\
1934\end{array}$ & $\begin{array}{c}1933 / \\
1934\end{array}$ & $\begin{array}{r}1933 / \\
1934\end{array}$ & $\begin{array}{c}1933 / \\
1934\end{array}$ & $\begin{array}{r}1933 / \\
1934\end{array}$ \\
\hline Soil depth $(\mathrm{cm})$ & 69 & 63 & 37 & 41 & 30 & 15 & 18 & - & - & - & - & - & 10 \\
\hline Aspect (deg.) & 180 & 135 & 250 & 260 & 260 & 290 & 320 & 200 & 200 & 210 & 280 & 155 & 155 \\
\hline Slope (deg.) & 6 & 2 & 1 & 2 & 5 & 15 & 15 & 9 & 20 & 20 & 2 & 5 & 2 \\
\hline Altitude (m a.s.1.) & 120 & 120 & 125 & 130 & 125 & 120 & 120 & 40 & 40 & 45 & 40 & 35 & 30 \\
\hline
\end{tabular}


APPENDIX 3

Vascular plant species composition along the Red Point Hills and Louisa Plains transects

\begin{tabular}{|c|c|c|c|c|c|c|c|c|c|c|c|c|c|}
\hline \multirow[b]{3}{*}{ Species* } & \multicolumn{7}{|c|}{ Red Point Hills Transect } & \multicolumn{6}{|c|}{ Louisa Plains Transect } \\
\hline & $0-10$ & $10-20$ & $20-30$ & $30-40$ & $40-50$ & $50-60$ & $60-70$ & $0-10$ & $10-20$ & $20-30$ & $30-40$ & $40-50$ & $50-60$ \\
\hline & $\mathrm{R} 1$ & $\mathrm{R} 2$ & $\mathrm{R} 3$ & R4 & $\mathrm{R} 5$ & R6 & $\mathrm{R} 7$ & L1 & $\mathrm{L} 2$ & L3 & L4 & L5 & L6 \\
\hline Eucalyptus aff. tenuiramis & 2.5 & 15 & 62.5 & 62.5 & 62.5 & 87.5 & 15 & 1 & 62.5 & 62.5 & 62.5 & 37.5 & 2.5 \\
\hline Melaleuca squarrosa & 38 & 37.5 & 37.5 & 37.5 & 15 & 0 & 0 & 38 & 37.5 & 2.5 & 62.5 & 37.5 & 0 \\
\hline Monotoca glauca & & 0 & 15 & 15 & 15 & 1 & 0 & 0 & 0 & 0 & 2.5 & 0 & 0 \\
\hline Gabnia grandis & 0 & 15 & 2.5 & 15 & 15 & 15 & 0 & 0 & 37.5 & 62.5 & 37.5 & 37.5 & 0 \\
\hline Zieria arborescens & 0 & 0 & 2.5 & 15 & 15 & 2.5 & 0 & 0 & 15 & 2.5 & 2.5 & 1 & 0 \\
\hline Banksia marginata & 2.5 & 37.5 & 0 & 15 & 15 & 37.5 & 37.5 & 15 & 1 & 0 & 2.5 & 37.5 & 15 \\
\hline Acacia verticillata & 0 & 1 & 15 & 2.5 & 37.5 & 15 & 0 & 0 & 15 & 37.5 & 0 & 37.5 & 1 \\
\hline Leptospermum scoparium & 15 & 2.5 & 2.5 & 2.5 & 37.5 & 37.5 & 15 & 0 & 0 & 0 & 0 & 0 & 2.5 \\
\hline Bauera rubioides & 0 & 2.5 & 0 & 2.5 & 37.5 & 37.5 & 2.5 & 88 & 1 & 1 & 2.5 & 15 & 15 \\
\hline Lomatia polymorpha & 0 & 0 & 0 & 2.5 & 2.5 & 2.5 & 1 & 1 & 62.5 & 2.5 & 2.5 & 2.5 & 2.5 \\
\hline Cenarrbenes nitida & & 0 & 15 & 2.5 & 0 & 1 & 0 & 0 & 0 & 0 & 0 & 0 & 0 \\
\hline Pteridium esculentum & 0 & 0 & 1 & 1 & 1 & 0 & 0 & 0 & 0 & 0 & 2.5 & 2.5 & 0 \\
\hline Dianella tasmanica & 0 & 0 & 0 & 1 & 0 & 2.5 & 0 & 0 & 0 & 0 & 2.5 & 1 & 0 \\
\hline Billardiera longifolia & 0 & 0.5 & 0.5 & 0.5 & I & 0 & 0 & 0 & 1 & 0 & 2.5 & 2.5 & 0 \\
\hline Ehrharta tasmanica & 0 & 0 & 0 & 0.5 & 1 & 1 & 0 & 0 & 0 & 0 & 0 & 0 & 0 \\
\hline Drymophila cyanocarpa & 0 & 0 & 1 & 0.5 & 0 & 0 & 0 & 0 & 0 & 0 & 0.5 & 0 & 0 \\
\hline Blechnum wattsii & 0 & 0 & 0 & 0.5 & 0 & 0 & 0 & 0 & 0 & 1 & 1 & 0.5 & 0 \\
\hline Gonocarpus teucrioides & 0 & 0 & 0 & 0.5 & 0 & 1 & 0 & 0 & 0 & 0 & 0 & 0 & 0 \\
\hline Phyllocladus aspleniifolius & 0 & 0 & 0 & 0.5 & 0 & 0 & 0 & 0 & 0 & 0 & 0 & 0 & 0 \\
\hline Pimelea linifolia & 1 & 1 & 0 & 0.5 & 0 & 1 & 0 & 0 & 0 & 0 & 0 & 0 & 0 \\
\hline Agastachys odorata & 15 & 15 & 0 & 0 & 2.5 & 2.5 & 0 & 0 & 0 & 0 & 0 & 0 & 0 \\
\hline Lycopodium fastigatum & 0 & 1 & 0 & 0 & 2.5 & 0 & 0 & 0 & 0 & 0 & 0 & 0 & 0 \\
\hline Phebalium squameum & 0 & 0 & 0 & 0 & 2.5 & 1 & 0 & 0 & 2.5 & 0 & 0 & 0 & 0 \\
\hline Cyathodes juniperina & 0 & 0 & 1 & 0 & 1 & 0 & 0 & 0 & 0 & 0 & 0 & 0 & 0 \\
\hline Boronia citriodora & 2.5 & 2.5 & 0 & 0 & 1 & 0 & 1 & 0 & 0 & 0 & 0 & 0 & 0 \\
\hline Empodisma minus & 1 & 2.5 & 0 & 0 & 1 & 1 & 2.5 & 2.5 & 0 & 1 & 0 & 0 & 2.5 \\
\hline Epacris impressa & 0 & 0 & 0 & 0 & 1 & 2.5 & 0 & 0 & 0 & 0 & 0 & 0 & 2.5 \\
\hline Schoenus tenuissimus & 1 & 1 & 0 & 0 & 1 & 1 & 0 & 0 & 0 & 0 & 0 & 0 & 1 \\
\hline Sprengelia incarnata & 1 & 1 & 0 & 0 & 1 & 0 & 1 & 0 & 0 & 0 & 0 & 0 & 1 \\
\hline Tasmannia lanceolata & 0 & 0 & 0.5 & 0 & 0 & 0 & 0 & 0 & 0 & 0 & 0 & 0 & 0 \\
\hline Acacia myrtifolia & 0 & 0 & 0 & 0 & 0 & 0 & 1 & 0 & 0 & 0 & 0 & 0 & 1 \\
\hline Allocasuarina monilifera & 0 & 0 & 0 & 0 & 0 & 0 & 37.5 & 15 & 0 & 0 & 0 & 0 & 37.5 \\
\hline Anopterus glandulosus & 0 & 0 & 0 & 0 & 0 & 0 & 0 & 0 & 0 & 2.5 & 0.5 & 0 & 0 \\
\hline Baumea tetragona & 1 & 0 & 0 & 0 & 0 & 0 & 0 & 0 & 0 & 0 & 0 & 0 & 0 \\
\hline Cassytha glabella & 0 & 0 & 0 & 0 & 0 & 0 & 0 & 0 & 0 & 0 & 0 & 1 & 0 \\
\hline Epacris lanuginosa & 0 & 2.5 & 0 & 0 & 0 & 0 & 1 & 0 & 0 & 0 & 0 & 0 & 0 \\
\hline Diplarrena latifolia & 0 & 0 & 0 & 0 & 0 & 0 & 0 & 0 & 1 & 0 & 0 & 1 & 1 \\
\hline Epacris heteronema & 0 & 0 & 0 & 0 & 0 & 0 & 1 & 0 & 0 & 0 & 0 & 0 & 0 \\
\hline Lindsaea linearis & 0 & 0 & 0 & 0 & 0 & 0 & 1 & 0 & 0 & 0 & 0 & 0 & 0 \\
\hline Gleichenia dicarpa & 1 & 1 & 0 & 0 & 0 & 1 & 37.5 & 2.5 & 1 & 37.5 & 15 & 2.5 & 0 \\
\hline Gymnoschoenus sphaerocephalus & 38 & 1 & 0 & 0 & 0 & 0 & 15 & 0 & 0 & 0 & 0 & 0 & 1 \\
\hline Hakea epiglottis & 0 & 0 & 0 & 0 & 0 & 0 & 0 & 0 & 0 & 0 & 0 & 0 & 15 \\
\hline Leucopogon collinus & 0 & 0 & 0 & 0 & 0 & 0 & 2.5 & 0 & 0 & 0 & 0 & 0 & 2.5 \\
\hline Lepidosperma ensiforme & 0 & 0 & 0 & 0 & 0 & 0 & 0 & 0 & 0 & 0 & 15 & 1 & 0 \\
\hline L. filiformis & 0 & 0 & 0 & 0 & 0 & 0 & 2.5 & 0 & 0 & 0 & 0 & 0 & 15 \\
\hline Leptospermum nitidum & 2.5 & 0 & 0 & 0 & 0 & 0 & 2.5 & 0 & 0 & 0 & 0 & 0 & 0 \\
\hline Leptocarpus tenax & 2.5 & 0 & 0 & 0 & 0 & 0 & 2.5 & 0 & 0 & 0 & 0 & 0 & 0 \\
\hline Lepyrodia sp. & 1 & 0 & 0 & 0 & 0 & 0 & 0 & 0 & 0 & 0 & 0 & 0 & 0 \\
\hline Melaleuca squamea & 15 & 37.5 & 0 & 0 & 0 & 0 & 2.5 & 0 & 0 & 0 & 0 & 0 & 0 \\
\hline Moss & 0 & 0 & 0 & 0 & 0 & 0 & 0 & 0 & 0 & 2.5 & 1 & 0 & 0 \\
\hline Patersonia fragilis & 0 & 0 & 0 & 0 & 0 & 0 & 1 & 0 & 0 & 0 & 0 & 0 & 0 \\
\hline Persoonia juniperina & 0 & 0 & 0 & 0 & 0 & 0 & 2.5 & 0 & 0 & 0 & 0 & 0 & 0 \\
\hline Pomaderris apetala & 0 & 0 & 0 & 0 & 0 & 0 & 0 & 0 & 0 & 37.5 & 0 & 0 & 0 \\
\hline Pultenaea daphnoides & 0 & 0 & 0 & 0 & 0 & 2.5 & 0 & 0 & 0 & 0 & 0.5 & 0 & 0 \\
\hline P. juniperina & 0 & 0 & 0 & 0 & 0 & 0 & 0 & 0 & 0 & 0 & 0 & 0.5 & 0 \\
\hline Restio complanatus & 0 & 0 & 0 & 0 & 0 & 0 & 1 & 0 & 0 & 0 & 0 & 0 & 0 \\
\hline R. hookeri & 0 & 0 & 0 & 0 & 0 & 0 & 2.5 & 0 & 0 & 0 & 0 & 0 & 0 \\
\hline Stylidium graminifolium & 0 & 0 & 0 & 0 & 0 & 0 & 1 & 0 & 0 & 0 & 0 & 0 & 0 \\
\hline Xyris sp. & 1 & 1 & 0 & 0 & 0 & 0 & 0 & 0 & 0 & 0 & 0 & 0 & 0 \\
\hline
\end{tabular}

* Nomenclature and synonyms follow Buchanan 1995, except Eucalyptus aff. tenuiramis. Percentage cover-abundances follow Braun-Blanquer scores in Mueller-Dombois \& Ellenberg (1974). 